\title{
Co-operative effect of glutathione depletion and selenium induced oxidative stress on AP1 and NFKB expression in testicular cells in vitro: insights to regulation of spermatogenesis
}

\author{
SONIA SHALINI AND MOHINDER P BANSAL*
}

Department of Biophysics, Panjab University, Chandigarh 160014, India

\begin{abstract}
Previous studies have shown that transcription factors, AP1 and NFKB exert important roles in the process by which selenium regulates spermatogenesis. Glutathione, an intracellular thiol, acts as a source of reducing power and aids in maintenance of the cellular redox status. The activities of selenium are closely related to the availability of glutathione. Presently, mouse testicular cells were cultured in the presence of BSO, a known glutathione depletor, to generate oxidative stress. Selenium (Se) was added as sodium selenite to these cells at concentrations of $0.5 \mu \mathrm{M}$ and $1.5 \mu \mathrm{M}$. It was observed that at $1.5 \mu \mathrm{M}$, Se acted as a pro-oxidant and significantly decreased the redox ratio. RT PCR analysis revealed that cjun, cfos expression increased in testicular cells cultured with Se compared to control. However, the major outcome was that the combined effect of Se supplementation and GSH depletion resulted in reduced expression of cjun and cfos while p65 expression increased. This suggests that selenium affects both these transcription factors differently. Our study indicates that though low levels of oxidative stress generated by moderate doses of selenium augments the expression of cjun and cfos, a robust increase in the ROS generation caused by the dual effect high levels of selenium and glutathione depletion leads to decrease in the expression of these genes. The present work substantiates our in vivo experiments and indicates the detrimental effect of excess selenium supplementation on male fertility.
\end{abstract}

Key terms: AP1, BSO, GSH, NFאB, oxidative stress, selenium, testicular cells.

\section{INTRODUCTION}

Oxidative stress due to excessive generation of reactive oxygen species (ROS) has been associated with defective sperm function and infertility (Sharma and Agarwal, 1996; Agarwal and Saleh, 2002). Selenium (Se), a essential trace element, plays an important role in the process of sperm development in mammals. It forms an important constituent of the enzyme glutathione peroxidase (GSH $\mathrm{Px}$ ) which is actively involved in the removal of both organic and inorganic peroxides (Rotruck et al., 1973). Selenium deficiency results in loss of GSH Px activity (Shalini and Bansal, 2005) and increase in oxidative stress.

Glutathione (GSH), a ubiquitous tripeptide thiol, is a vital intra-and extracellular protective antioxidant which plays a key role in the control of male infertility (Luberda, 2005). $\gamma$ glutamylcysteine synthetase $(\gamma \mathrm{GCS})$ is a rate limiting enzyme in GSH synthesis. In recent years the close involvement of glutathione in selenium metabolism and bioactivity has attracted much attention. First, it is known that selenium plays a crucial role in the function of many important enzymes, such as glutathione peroxidase and thioredoxin reductase which are closely related to the antioxidant defense mechanism or cell growth regulation (Powis et al., 1997; Ganther, 1999). Secondly, it is well understood that selenite, the most commonly used seleno organic compound, undergoes thiol dependent reduction to form selenide before

\footnotetext{
* Corresponding author: e-mail: mpbansal@pu.ac.in, Tel.: 0172 2534120, Fax: 01722534118
}

Received: December 15, 2006. In revised form: July 4, 2007. Accepted: July 12, 2007 
being incorporated into specific selenoproteins as selenocysteine (Stadtman, 1996). Thirdly, it has been demonstrated that reaction of selenite with reduced form of glutathione (GSH) during metabolism leads to the formation of reactive oxygen species, ROS (Shen et al., 2000).

The transcription factors, AP1 and NFkB are sensitive to oxidants, antioxidants and the conditions which affect the intracellular redox state (Schulze Osthoff et al., 1995). They are also associated with cellular functions of proliferation and differentiation (Pahl, 1999; Behrens et al., 2002). Further, their activation is known to be modulated by selenium (Spyrou et al., 1995; Kim and Stadtman, 1997). In light of these facts we examined the expression of redox sensitive transcription factors activator protein $1(\mathrm{AP} 1)$ and nuclear factor $\kappa \mathrm{B}(\mathrm{NF} \kappa \mathrm{B})$ (Shalini and Bansal, 2005; Shalini and Bansal, 2006) in mice fed diets containing different Se levels and observed that the activity of both these nuclear proteins are modulated. Redox regulation of spermatogenesis by Se thus appeared to be mediated through these transcription factors.

Although it is known that GSH is closely involved in $\mathrm{Se}$ metabolism and bioactivity, the exact mechanisms are still not clear. Our previous in vivo studies indicated modulation of AP1 and NFKB expression due to different Se status. To clearly ascertain these effects, in the present study, testicular cells were cultured in the presence of buthionine sulfoximine, BSO (glutathione depletor) alone and along with selenium (as sodium selenite) at concentrations of $0.5 \mu \mathrm{M}$ and $1.5 \mu \mathrm{M}$.

\section{METHODS}

Testicular cell culture: Testicular cells were isolated from Balb/c mice by the method of Steinberger (1975) with minor modifications. After gently decapsulating the testis, seminiferous tubules were teased gently by pressing between two frosted slides to get a cell suspension in PBS. The suspension was then filtered through a stainless steel mesh to remove cell aggregates and tissue debris. The filtrate was centrifuged at $1000 \mathrm{~g}$ for $10 \mathrm{~min}$ at $4^{\circ} \mathrm{C}$ to obtain a cell pellet. The cells were suspended in DMEM supplemented with $5 \%$ FCS. Cells were counted using a haemocytometer and plated at a concentration of $0.4 \times 10^{6}$ cells/well. Selenium was added as sodium selenite at a final concentration of $1.5 \mu \mathrm{M}$ or $0.5 \mu \mathrm{M}$ either alone or together with BSO $(10 \mathrm{nM})$. The cells were kept at $32^{\circ} \mathrm{C}$ in a humidified atmosphere of $5 \% \mathrm{CO}_{2}$ for $4 \mathrm{hr}$. After this the cells were collected from the wells and centrifuged at $10,000 \mathrm{~g}$ at $4^{\circ} \mathrm{C}$ to obtain a pellet.

MTT assay: Cytotoxic effects of different concentrations of selenium and BSO on testicular cells were determined as a function of cellular mitochondrial activity by MTT assay (Alley et al., 1988). To 100 $\mu l$ of the supernatant added $10 \mu \mathrm{l}$ of MTT solution $(5 \mathrm{mg} / \mathrm{ml}$ in $0.1 \mathrm{M} \mathrm{PBS} ; \mathrm{pH} 7.4)$ and incubated in a humidified atmosphere of $5 \% \mathrm{CO}_{2}$ at $32^{\circ} \mathrm{C}$ for $4 \mathrm{hr}$. After discarding the supernatant, the formazan crystals so obtained were dissolved in $200 \mu \mathrm{l}$ of DMSO. The absorbance was read at a wavelength of $580 \mathrm{~nm}$ using an ELISA reader (Stat fax 325). Blanks contained DMSO only.

Determination of intracellular GSH content: The level of total and oxidized glutathione (GSSG) was measured by the fluorimetric method of Hissin and Hilf (1976). This method is based on the principle that glutathione reacts specifically with o pthaldehyde (OPT) at $\mathrm{pH} 8$ and with GSSG at $\mathrm{pH} 12$ resulting in the formation of a highly fluorescent product which is activated at $350 \mathrm{~nm}$ with an emission at 420 $\mathrm{nm}$. Reduced glutathione (GSH) levels were obtained by subtracting the values of GSSG levels from the total glutathione levels. Results were expressed as nmoles of GSH or GSSG/mg protein. Protein estimation was done according to the method of Lowry et al., (1951).

RNA isolation and RT PCR: Total RNA was isolated from the testis using TRI reagent (RNA, DNA, and protein isolation reagent) as per manufacturer's protocol (Molecular Research Center, Inc. 
Cincinnati, $\mathrm{OH}$ ) and the quality of isolated RNA was checked on $1.2 \%$ formaldehyde agarose gel electrophoresis. PCR analyses were carried out in $50 \mu$ using the QIAGEN one step RT PCR kit. Optimal oligonucleotide primer pairs for RT PCR were selected and are listed in Table I. Primers for PCR were designed using the Clone Manager Software. $3 \mu \mathrm{g}$ RNA was used for each amplification reaction. After an initial denaturation step of $1 \mathrm{~min}$ at $94^{\circ} \mathrm{C}, 35$ amplification cycles were performed. Each cycle included an initial denaturation step at $94^{\circ} \mathrm{C}$ for $45 \mathrm{~s}$, annealing at $58.8^{\circ} \mathrm{C}$ (cjun, cfos) and $56^{\circ} \mathrm{C}$ $(\gamma \mathrm{GCS})$ for $45 \mathrm{~s}$ and extension at $72^{\circ} \mathrm{C}$ for $45 \mathrm{~s}$. A final extension step of $5 \mathrm{~min}$ at $72^{\circ} \mathrm{C}$ was performed in order to complete the PCR reaction. The amplified product was analyzed on $1.5 \%$ agarose gel electrophoresis and densitometric analysis of the bands was done using Image J software (NIH).

Statistical analysis: The difference between the Means \pm SD for control and treated groups were examined by using the Student's t test for unpaired values. Values are a mean of four independent sets of experiments. Statistical differences of $p$ values at the level of 0.05 or less were considered significant. Densitometric analysis of bands was done by ImageJ software (NIH).

\section{RESULTS}

\section{1) Cell Viability by MTT assay}

Exposing cells to $10 \mathrm{nM}$ BSO did not cause any change in the absorbance (Table II).

Selenium (as selenite) exposure alone caused a dose dependent inhibition. It thus appears that although BSO is not cytotoxic, selenium shows dose dependent cytotoxicity. Presently, selenium was used at $0.5 \mu \mathrm{M}$ and $1.5 \mu \mathrm{M}$ concentration for further experiments wherein $90 \%$ cells were viable.

\section{2) Effect of Selenium and Buthionine Sulfoximine (BSO) on Glutathione Levels}

Reduced Glutathione (GSH): Exposure of testicular cells to $10 \mathrm{nM}$ BSO caused a significant decrease in the GSH levels. Selenium alone also resulted in a significant decline in the levels of reduced glutathione at both the concentrations used (Table III).

Oxidized Glutathione (GSSG): There was a significant decrease in the levels of oxidized glutathione (GSSG), when testicular cells were exposed to $10 \mathrm{nM}$ BSO compared to the control cells. No change was observed in cells exposed to varying concentrations of selenium compared to the control cells or when incubated simultaneously with selenium and BSO (Table III).

TABLE I

Primer pairs used

\begin{tabular}{|c|c|c|c|c|}
\hline Gene & Primer pair & & Reference & Product size \\
\hline \multirow[t]{2}{*}{ cjun } & Sense & 5' ATG GGC ACA TCA CCA CTA CA 3' & \multirow[t]{2}{*}{ ACCESSION X12740 } & \multirow[t]{2}{*}{$723 b p$} \\
\hline & Antisense & $5^{\prime}$ TGA GTT GGC ACC CAC TGT TA 3' & & \\
\hline \multirow[t]{2}{*}{ cfos } & Sense & 5' ATG GGC TCT CCT GTC AAC AC 3' & \multirow[t]{2}{*}{ ACCESSION V00727 } & \multirow[t]{2}{*}{$715 b p$} \\
\hline & Antisense & 5' ATG ATG CCG GAA ACA AGA AG 3' & & \\
\hline \multirow[t]{2}{*}{ p65 } & Sense & 5' TGG CGA GAG AAG CAC AGA TA 3' & ACCESSION & \multirow[t]{2}{*}{$272 b p$} \\
\hline & Antisense & 5’ TGT TGG TCT GGA TTC GCT G 3’' & M61909 & \\
\hline \multirow[t]{2}{*}{$\gamma \mathrm{GCS}$} & Sense & 5' CCT TCT GGC ACA GCA CGT TG 3' & \multirow{2}{*}{$\begin{array}{l}\text { Yan and Meister, } \\
1990\end{array}$} & \multirow[t]{2}{*}{$346 b p$} \\
\hline & Antisense & 5' TAA GAC GGC ATC TCG CTC CT 3' & & \\
\hline \multirow[t]{2}{*}{$\beta$ actin } & Sense & 5' ATC CGT AAA GAC CTC TAT GC 3' & \multirow[t]{2}{*}{ Yamada et al., 1996} & \multirow[t]{2}{*}{$287 \mathrm{bp}$} \\
\hline & Antisense & 5' AAC GCA GCT CAG TAA CAG TC 3' & & \\
\hline
\end{tabular}


Redox Ratio: No change in redox ratio was observed in the cells exposed to BSO when compared to control cells. However, selenium at a concentration of $1.5 \mu \mathrm{M}$ significantly reduced the redox ratio of testicular cells (Table III).

\section{3) $m R N A$ expression studies}

i) $\gamma$ Glutamylcysteine synthetase $(\gamma$ GCS $)$ : RT PCR products with the expected size of 346 bp were obtained (Fig. 1a). The mRNA expression of $\gamma \mathrm{GCS}$ increased significantly in testicular cells incubated with BSO as compared to the control cells. Selenium alone resulted in significant dose dependent increase in the mRNA expression of this gene compared to control cells. No change was observed when cells were co incubated with selenium and BSO compared to those incubated with selenium alone (Fig. 1b).

ii)cjun: Bands of expected size of $723 \mathrm{bp}$ were obtained for cjun (Fig. 2a). cjun expression significantly increased in testicular cells incubated with BSO as compared to the control cells.

Selenium alone significantly increased the abundance of the transcripts for this gene in a dose dependent manner compared to the control cells. A significant decrease was observed between cells that were incubated simultaneously with selenium and BSO $(1.5 \mu \mathrm{M}$ and $0.5 \mu \mathrm{M})$ compared to those exposed to selenium alone (Fig. 2b). iii) cfos: Bands of expected size of 715 bp were obtained for cfos (Fig. 3a). cfos expression significantly increased in testicular cells incubated with BSO as compared to the control cells.

Selenium alone caused significant increase in mRNA expression at $1.5 \mu \mathrm{M}$ concentration compared to the control cells. A significant decrease was observed between cells that were incubated simultaneously with selenium and BSO (1.5 $\mu \mathrm{M}$ and $0.5 \mu \mathrm{M})$ compared to those exposed to selenium alone (Fig. 3b).

TABLE II

Effect of different concentrations of selenium and BSO on viability of mouse testicular cells by MTT assay

Type of treatment

$\begin{array}{ll}\text { Control } & 0.369 \pm 0.02 \\ \text { BSO only }(10 \mathrm{nM}) & 0.365 \pm 0.01\end{array}$

Se concentration $(\mu \mathrm{M})$ Selenium Selenium + BSO

$\begin{array}{lll}3 & 0.271 \pm 0.01^{\mathrm{c}} & 0.269 \pm 0.01\end{array}$

$\begin{array}{lll}0.294 \pm 0.02^{\mathrm{b}} & 0.288 \pm 0.01\end{array}$

$\begin{array}{lll}1.5 & 0.341 \pm 0.01^{\mathrm{a}} & 0.322 \pm 0.02\end{array}$

$\begin{array}{lll}1.0 & 0.356 \pm 0.01 & 0.348 \pm 0.01\end{array}$

$0.5 \quad 0.371 \pm 0.01 \quad 0.366 \pm 0.01$

Values are Mean \pm SD of 4 observations. ${ }^{\mathrm{a}} \mathrm{p}<0.05$ ${ }^{\mathrm{b}} \mathrm{p}<0.01$ and ${ }^{\mathrm{c}} \mathrm{p}<0.001$ represent comparison of cells exposed to different Se concentrations with respect to control cells.

TABLE III

Effect of different concentrations of selenium and BSO on reduced glutathione (GSH), oxidized glutathione (GSSG) levels and redox ratio (GSH/GSSG) in mouse testicular cells

\begin{tabular}{lccc}
\hline Type of treatment & GSH (nmoles/mg protein) & GSSG (nmoles/mg protein) & GSH/GSSG \\
\hline Control & $25.10 \pm 1.18$ & $2.15 \pm 0.34$ & $11.87 \pm 2.03$ \\
BSO only $(10 \mathrm{nM})$ & $16.00 \pm 3.36^{\mathrm{h}}$ & $1.70 \pm 0.08^{\mathrm{g}}$ & $9.40 \pm 1.94$ \\
$\mathrm{Se}(1.5 \mathrm{M})$ & $20.85 \pm 1.04^{\mathrm{b}}$ & $2.52 \pm 0.25$ & $8.28 \pm 0.82^{\mathrm{a}}$ \\
$\mathrm{Se}(0.5 \mathrm{M})$ & $22.77 \pm 1.15^{\mathrm{a}}$ & $2.32 \pm 0.23$ & $9.85 \pm 0.94$ \\
$\mathrm{BSO}+\mathrm{Se}(1.5 \mu \mathrm{M})$ & $18.90 \pm 1.59$ & $2.35 \pm 0.46$ & $8.41 \pm 2.61$ \\
$\mathrm{BSO}+\mathrm{Se}(0.5 \mu \mathrm{M})$ & $21.42 \pm 1.43$ & $1.82 \pm 0.17$ & $11.82 \pm 1.75$ \\
\hline
\end{tabular}

GSH and GSSG levels decreased in cells exposed to BSO while significant decrease in the cellular redox ratio was observed when incubated with 1.5 M Se. Values are Mean \pm SD of 4 observations. ${ }^{a} \mathrm{p}<0.05$ and ${ }^{b} \mathrm{p}<0.01$ represents comparison of cells exposed to different Se concentrations with respect to control cells. ${ }^{\mathrm{a} p}<0.05$ and ${ }^{b} \mathrm{p}<0.01$ represents comparison between cells exposed to $10 \mathrm{nM}$ BSO with respect to control cells. 


\section{Figure 1(a)}

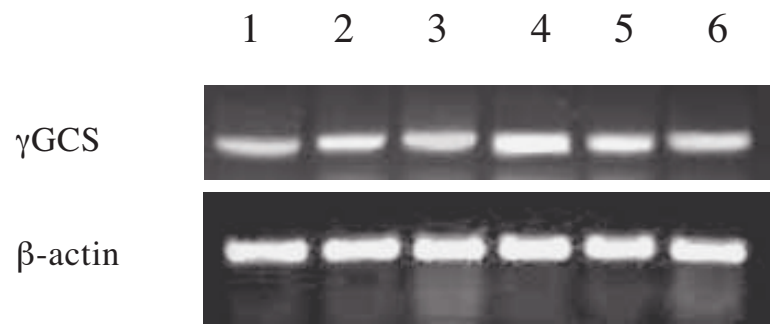

(346 bp)

(287 bp)

Lane 1: Control

Lane 4: BSO (10 nM)
Lane 1: Se $(1.5 \mu \mathrm{M})$

Lane 3: Se $(0.5 \mu \mathrm{M})$

Lane 5: Se $(1.5 \mu \mathrm{M})+\mathrm{BSO} \quad$ Lane 6: Se $(0.5 \mu \mathrm{M})+\mathrm{BSO}$

Figure 1(b)

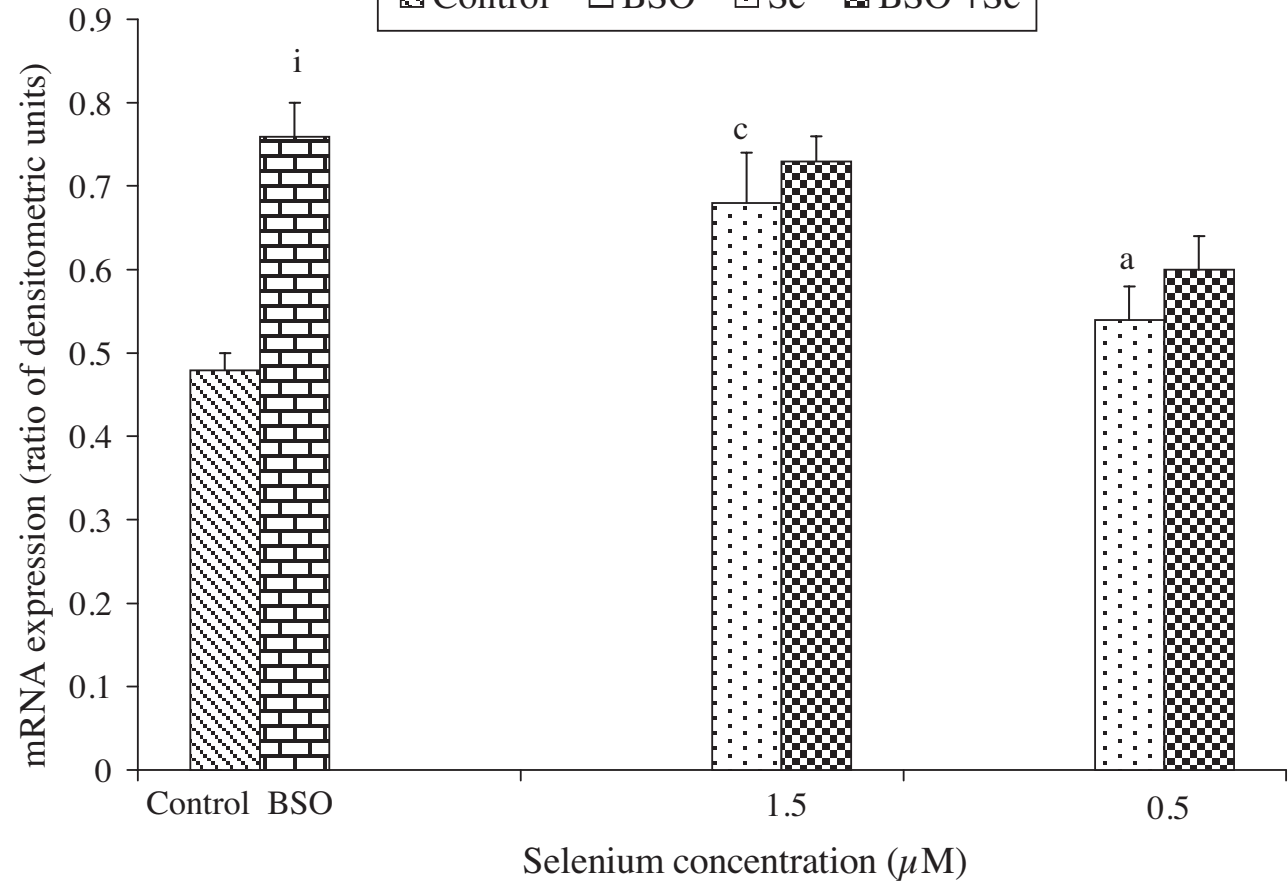

Figure 1(a): Influence of different concentrations of selenium and buthionine sulfoximine (BSO) on $\gamma$ GCS mRNA expression in testicular cells by RT-PCR. (b): Densitometric analysis of $\gamma$ GCS expression. Values are Mean $\pm S D$ of 4 observations. ${ }^{a} p<0.05$ and ${ }^{c} p<0.001$ represents comparison of cells exposed to different Se concentrations with respect to control cells. ${ }^{i} p<0.001$ represents comparison of cells exposed to $10 \mathrm{nM} B S O$ with respect to control cells. 
Figure 2(a)

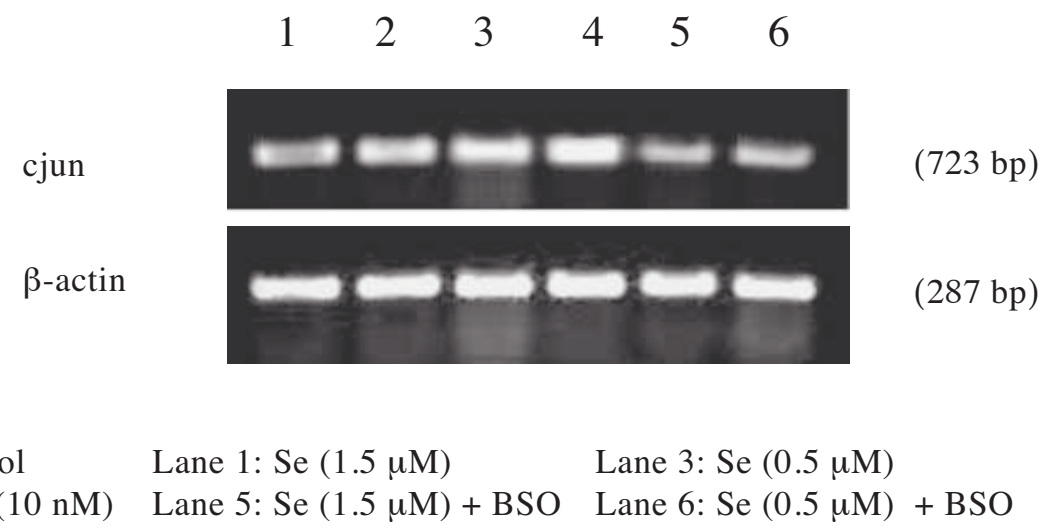

$\begin{array}{lll}\text { Lane 1: Control } & \text { Lane 1: } \mathrm{Se}(1.5 \mu \mathrm{M}) & \text { Lane 3: Se }(0.5 \mu \mathrm{M}) \\ \text { Lane 4: BSO }(10 \mathrm{nM}) & \text { Lane 5: } \mathrm{Se}(1.5 \mu \mathrm{M})+\text { BSO } & \text { Lane 6: Se }(0.5 \mu \mathrm{M})+\text { BSO }\end{array}$

Figure 2(b)

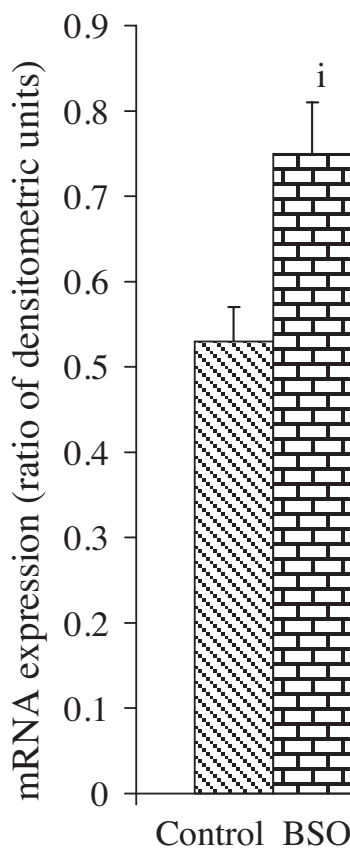

$\mathrm{B}$ Control $\mathbf{9} \mathrm{BSO} \quad \square \mathrm{Se} \quad \mathrm{BSO}+\mathrm{Se}$

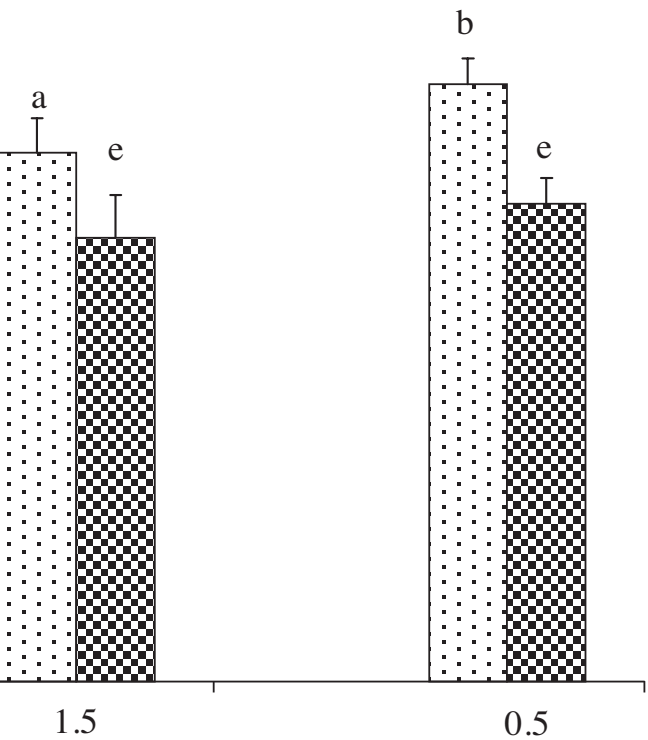

Selenium concentration $(\mu \mathrm{M})$

Figure 2(a): Influence of different concentrations of selenium and buthionine sulfoximine (BSO) on cjun mRNA expression in testicular cells by RT-PCR. (b): Densitometric analysis of cjun expression. Values are Mean $\pm S D$ of 4 observations. ${ }^{a} p<0.05$ and ${ }^{b} p<0.01$ represents comparison of cells exposed to different Se concentrations with respect to control cells. ${ }^{e} p<0.01$ represents comparison of cells exposed simultaneously to Se and BSO with the cells exposed to Se alone. ${ }^{i} p<0.001$ represents comparison of cells exposed to $10 \mathrm{n} \mathrm{M}$ BSO with respect to control cells. 
Figure 3(a)

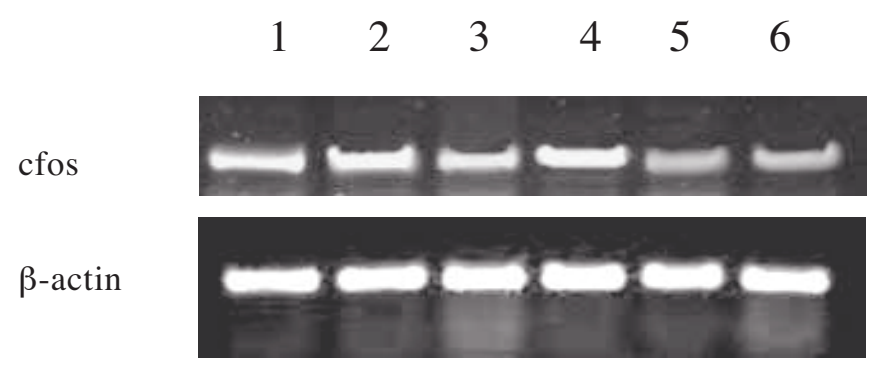

Lane 1: Control Lane 1: Se $(1.5 \mu \mathrm{M}) \quad$ Lane 3: Se $(0.5 \mu \mathrm{M})$

Lane 4: BSO $(10 \mathrm{nM}) \quad$ Lane 5: Se $(1.5 \mu \mathrm{M})+$ BSO Lane 6: Se $(0.5 \mu \mathrm{M})+\mathrm{BSO}$

Figure 3(b)

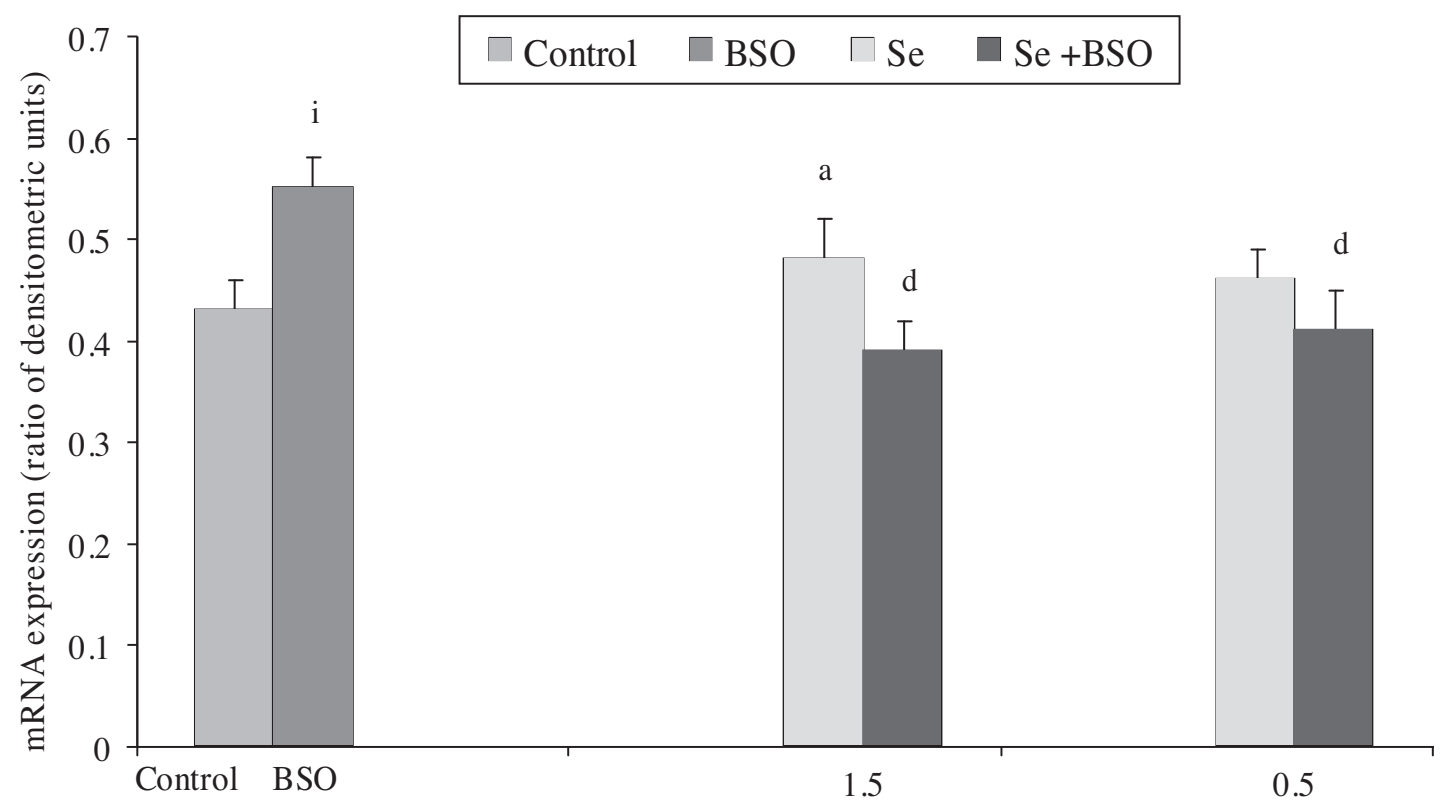

Selenium concentration $(\mu \mathrm{M})$

Figure 3(a): Influence of different concentrations of selenium and buthionine sulfoximine (BSO) on cfos mRNA expression in testicular cells by RT-PCR. (b): Densitometric analysis of cfos expression. Values are Mean $\pm S D$ of 4 observations. ${ }^{a} p<0.05$ represents comparison of cells exposed to Se with respect to control cells. ${ }^{d} p<0.05$ represents comparison of cells exposed simultaneously to Se and BSO with the cells exposed to Se alone. ${ }^{i} p<0.001$ represents comparison of cells exposed to $10 \mathrm{nM} B S O$ with respect to control cells. 
iv) p65: Bands of expected size of 272 bp were obtained for p65 (Fig 4a). The p65 gene expression increased significantly in testicular cells incubated with BSO as compared to the control cells. Selenium alone caused significant increase in mRNA expression at $1.5 \mu \mathrm{M}$ concentration compared to the control cells. A significant increase was observed between cells that were incubated simultaneously with selenium and BSO (1.5 $\mu \mathrm{M}$ selenium) compared to those exposed to selenium alone (Fig 4b).

\section{DISCUSSION}

Glutathione is the major intracellular antioxidant involved in the maintenance of the thiol moieties of proteins and reduced forms of many other molecules (Meister and Anderson, 1983; Meister, 1984). It exerts crucial role in Se metabolism also. The activities of transcription factors AP1 (cJun, cFos) and NFKB are dependent on their cellular environment. In both these proteins oxidation of critical cysteine residues (Cys 154 in Fos, Cys 272 in Jun and Cys 62 in p50) alters their binding and activation pattern (Abate et al., 1990; Matthews et al., 1993). Buthionine sulfoximine (BSO) is a compound that effectively retards the synthesis of gGCS and is commonly used to deplete cells of intracellular GSH (Anderson, 1998).

Exposure of testicular cells to $10 \mathrm{nM}$ BSO resulted in a significant decrease in GSH and GSSG levels. Selenium alone resulted in a dose dependent decline in the levels of reduced glutathione compared to control cells. This can be attributed to the enzyme GSH Px which uses GSH to reduce cellular peroxides consuming reduced glutathione in this process. During this process low molecular weight selenium compounds such as selenodiglutathione, other selenotrisulfides and selenides are also formed by interaction of selenium with reduced glutathione (Shen et al., 2001). The cellular redox ratio (GSH/ GSSG) was unaltered by BSO. On the other hand, redox ratio declined significantly in cells exposed to selenium at a concentration of $1.5 \mu \mathrm{M}$. This indicates that selenium acts as a pro-oxidant at this concentration and contributes towards building up of an oxidative environment.

BSO exposure increased $\gamma \mathrm{GCS}$ expression. Selenite alone also caused a dose dependent increase in its expression. In general the activity of $\gamma \mathrm{GCS}$ determines the rate of glutathione synthesis (Meister and Anderson, 1983) and the reaction is catalyzed by feedback inhibition of GSH. Exposure of rat lung/alveolar epithelial cells in vitro to oxidants such as $\mathrm{H}_{2} \mathrm{O}_{2}$ causes an initial depletion of GSH which is concomitant with increased mRNA expression for $\gamma$ GCS gene (Tian et al., 1997; Rahman et al., 1998a). Since selenite caused GSH depletion in a dose dependent manner and is also known to generate ROS, this might be responsible for the observed increase in $\gamma \mathrm{GCS}$ expression.

Further, it was observed that cjun and cfos mRNA levels were elevated in BSO depleted cells. Putative AP1 sites are present in $\gamma$ GCS gene (Tanaka et al., 1998; Rahman et al., 1998b) and this might be responsible for increased mRNA expression for this gene. A role of NFKB in modulation of $\gamma$ GCS gene expression has also been suggested. Some researchers have shown that blocking the activation of NFKB which is present at the promoter of $\gamma \mathrm{GCS} \mathrm{HS}$ gene, by various strategies prevented oxidant/cytokine induced increase in its expression in mouse endothelial cells and hepatocytes (Cai et al., 1997; Iwanga et al., 1998). p65 mRNA expression increased presently in cells exposed to BSO. Hence, it is likely that either or both these proteins might be involved in the process resulting in increased $\gamma \mathrm{GCS}$ expression.

cjun and cfos mRNA expression was induced in BSO treated cells. Intracellular glutathione levels regulate Jun and Fos induction (Bergelson et al., 1994). Increase in the expression of cjun and cfos genes due to loss of GSH has been reported (Tormos et al., 2004). Oguro et al., (1998) also observed that GSH depletion enhanced cJun phosphorylation and AP1 binding indicating activation of this transcription factor. Since activation of AP1 requires de novo synthesis, it is likely that this is achieved by increased expression of these genes. 
Figure 4(a)

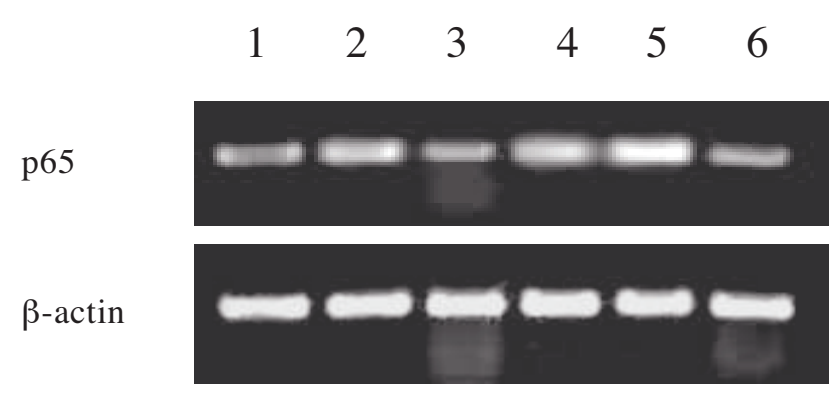

(287 bp)

Lane 1: Control

Lane 1: $\mathrm{Se}(1.5 \mu \mathrm{M})$

Lane 3: $\mathrm{Se}(0.5 \mu \mathrm{M})$

Lane 4: BSO (10 NM) Lane 5: Se $(1.5 \mu \mathrm{M})+$ BSO Lane 6: Se $(0.5 \mu \mathrm{M})+\mathrm{BSO})$

Figure 4(b)

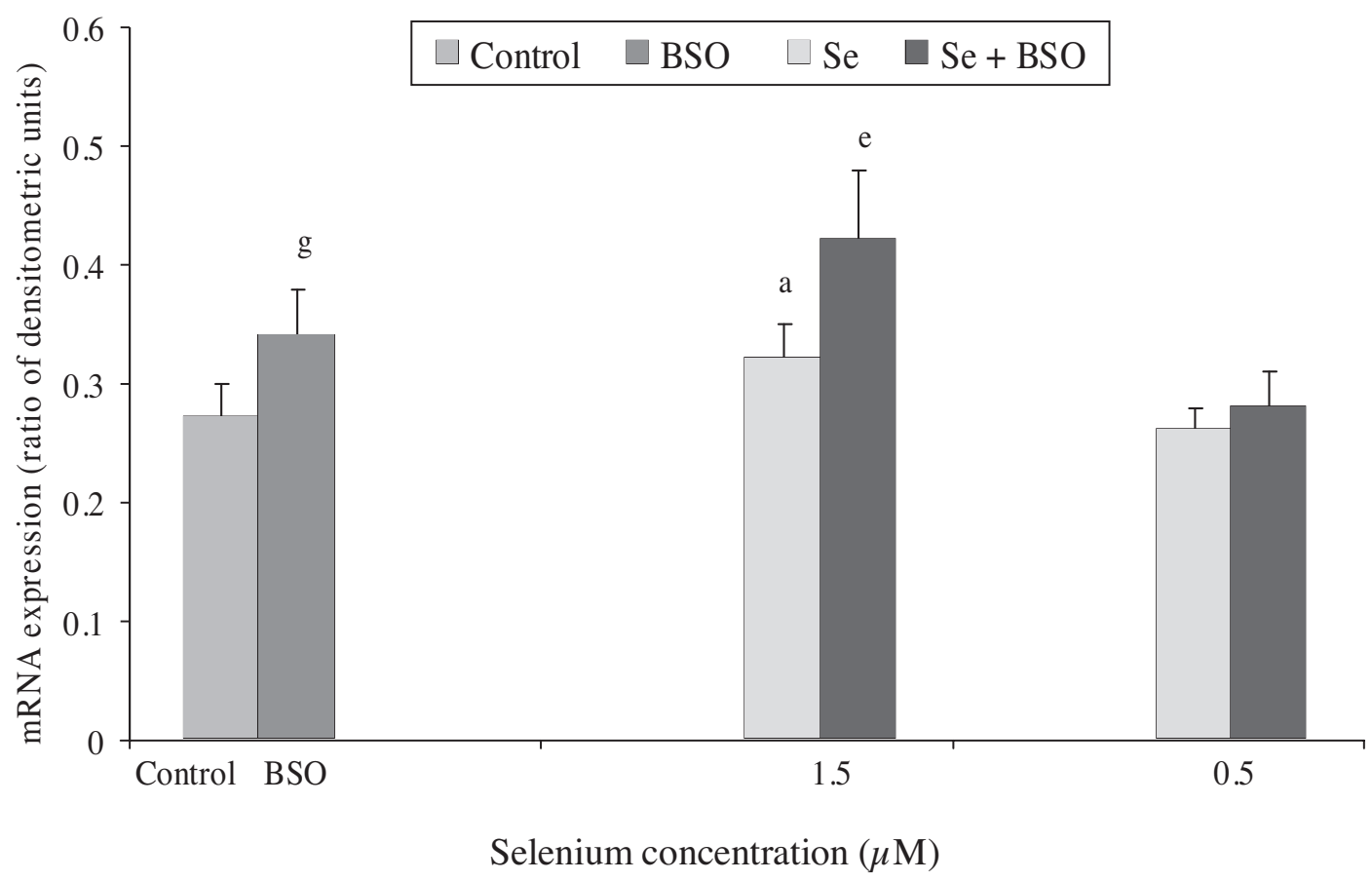

Figure 4a: Influence of different concentrations of selenium and buthionine sulfoximine (BSO) on p65 mRNA expression in testicular cells by RT-PCR. (b): Densitometric analysis of p65 expression. Values are Mean $\pm S D$ of 4 observations. ${ }^{a} p<0.05$ represents comparison of cells exposed to Se with respect to control cells. ${ }^{e} p<0.01$ represents comparison of cells exposed simultaneously to Se and BSO with the cells exposed to Se alone. ${ }^{g} p<0.05$ represents comparison of cells exposed to 10 nM BSO with respect to control cells. 
Selenium supplementation also led to increase in cjun $(1.5 \mu \mathrm{M}$ and $0.5 \mu \mathrm{M})$ and cfos $(1.5 \mu \mathrm{M})$ expression compared to control cells but it was substantially less compared to the BSO treated cells. Enhanced transcription of cjun and cfos has been observed in rat hippocampus cells cultured along with selenium (Tian et al., 2002). Oxidative stress generated due to high selenium levels, might be a causative factor. However when cells were co incubated with selenium and BSO, expression of both cjun and cfos decreased compared to the cells treated with selenium alone at $1.5 \mu \mathrm{M}$ and $0.5 \mu \mathrm{M}$ concentration. This indicates that though low levels of oxidative stress generated in by moderate doses of selenium augments the expression of cjun and cfos, a robust increase in the ROS generation caused by the dual effect high levels of selenium and glutathione depletion leads to decrease the mRNA of these genes probably due to interference with the DNA binding activity and de novo synthesis of these proteins (Morel and Barouki, 1999). In our previous in vivo studies Se deficiency as well as excess was associated with increased lipid peroxidation and decrease in GSH levels and thus explains the observed decrease in cjun and cfos expression in both selenium-deficient and selenium-excess treated groups. The product of both these genes forms AP1 which is known to significantly affect the proliferation and differentiation functions during spermatogenesis. Our studies strongly suggest that high Se levels generate excessive ROS which instead of inducing cause repression.

BSO exposure increased p65 mRNA expression. Selenium at a concentration of $1.5 \mu \mathrm{M}$ caused increase in p65 expression and co incubation with BSO led to further increase. $\mathrm{NF \kappa B}$ is redox sensitive and is activated by ROS. Increase in ROS generation was accompanied with increase in p65 mRNA expression in some pathological conditions such as rat acute necrotizing pancreatitis (Long et al., 2005). This indicates that increase in oxidative stress either due to BSO (decrease in GSH) or selenium supplementation (which decreases GSH and generates superoxide radical) results in increased p65 expression.

In conclusion, present study indicates that redox sensitive transcription factors AP1 and NF $\kappa \mathrm{B}$ are regulated differently. Mild oxidative stress enhanced the expression of cjun, cfos. On the other hand excessive ROS accumulation caused by combined effect of selenium exposure and glutathione deficiency caused repression. The expression of NFkB p65subunit was however induced. AP1 expression is often related to cell proliferation and differentiation. This explains the reason for reduced number of spermatids and spermatozoa observed previously in our in vivo studies. Activation of NFкB is pro-apoptotic. This study clearly points out that the mechanism by which selenium is responsible for the reduced fertility involves redox sensitive signaling proteins AP1 and NFKB.

\section{ACKNOWLEDGMENT}

The financial support provided by CSIR, New Delhi, India is deeply acknowledged.

\section{REFERENCES}

ABATE C, PATEL L, RAUSHER FJ, CURRAN T (1990) Redox regulation of Fos and Jun DNA binding activity in vitro. Science 249: 11571161

AGARWAL A, SALEH RA (2002) Role of oxidants in male infertility: rationale, significance and treatment. Urol Clin North Am 29(4): 817827

ALLEY MC, SCUDIERO DA, MONKS A, HURSEY ML, CZERWINSKI MJ, FINE DL, ABBOTT BJ, MAYO JG, SHOEMAKER RH, BOYD MR (1988) Feasibility of drug screening with panels of human tumor cell lines using a microculture tetrazolium assay. Cancer Res 48: 589601

ANDERSON ME (1998) Glutathione: an overview of biosynthesis and modulation. Chem Biol Interact 111 112: 114

BEHRENS A, SIBILIA M, DAVID JP, MOHLE STEINLEIN U, TRONCHE F, SCHUTZ G, WAGNER EF (2002) Impaired postnatal hepatocyte proliferation and liver regeneration in mice lacking $\mathrm{c}$ jun in the liver. EMBO J 21(7): 17821790

BERGELSON S, PINKUS R, DANIEL V (1994) Intracellular glutathione levels regulate Fos/Jun induction and activation of glutathione $\mathrm{S}$ transferase gene expression. Cancer Res 54: 3640

CAI J, HUANG Z, LU SC (1997) Differential regulation of $\gamma$ glutamylcysteine synthetase heavy and light subunit gene expression. Biochem J 326: 167172

GANTHER HE (1999) Selenium metabolism, selenoproteins and mechanisms of cancer prevention: 
complexities with thioredoxin reductase. Carcinogenesis 20: 16571666

HISSIN PJ, HILF R (1976) A fluorometric method for determination of oxidized and reduced glutathione in tissues. Anal Biochem 74: 214226

IWANGA M, MORI K, IIDA T (1998) Nuclear factor $\kappa$ B dependent induction of $\gamma$ glutamylcysteine synthetase by ionizing radiation in $\mathrm{T} 98 \mathrm{G}$ human glioblastoma cells. Free Radic Biol Med 24: 12561268

KIM IY, STADTMAN TC (1997) Inhibition of NF $\kappa B$ DNA binding and nitric oxide induction in human $\mathrm{T}$ cells and lung adenocarcinoma cells by selenite treatment. Proc Natl Acad Sci USA 94: 1290412907

LONG J, SONG N, LIU XP, GUO KJ, GUO RX (2005) Nuclear factor kappaB activation on the reactive oxygen species in acute necrotizing pancreatitic rats. World J Gastroenterol 11(27): 42774280

LOWRY OH, ROSEBROUGH NJ, FARR AL, RANDELL RJ (1951) Protein measurement with folin phenol reagent. J Biol Chem 193: 265275

LUBERDA Z (2005) The role of glutathione in mammalian gametes. Reprod Biol 5(1): 517

MATTHEWS JR, KASZUBSKA W, TURCATTI G, WELLS T NC, HAY RT (1993) Role of cysteine 62 in DNA recognition by the p50 subunit of NF $\kappa B$. Nucleic Acids Res 21: 17271734

MEISTER A (1984) New aspects of glutathione biochemistry and transport. Selective alteration of glutathione metabolism. Fed Proc 43: 30313042

MEISTER A, ANDERSON ME (1983) Glutathione. Annu Rev Biochem 52: 711760

MOREL Y, BAROUKI R (1999) Repression of gene expression by oxidative stress. Biochem J 342 (3): 481 496

OGURO T, HAYASHI M, NAKAJO S, NUMAZAWA S, YOSHIDA T (1998) The expression of heme oxygenase 1 gene responded to oxidative stress produced by phorone, a glutathione depletor, in the rat liver. The relevance to activation of c Jun $\mathrm{N}$ terminal kinase. J Pharmacol ExpTher 287: 773778

PAHL HL (1999) Activators and target genes of Rel/NF kappaB transcription factors. Oncogene 18(49): 6853 6866

POWIS G, GASDASKA JR, GASDAKA PV, BERGGREN M, KIRKPATRICK DL, ENGMAN L, COTGREVE IA, ANGULO M, BAKER A (1997) Selenium and the thioredoxin redox system: effects on cell growth and death. Oncol Res 9: 303312

RAHMAN I, BEL A, MULIER B, DONALDSON K, MACNEE W (1998a) Differential regulation of glutathione by oxidants and dexamethasone in alveolar epithelial cells. Am J Physiol Lung Cell Mol Physiol 275: L80 L86

RAHMAN I, SMITH CAD, ANTONICELLI F, MACNEE W (1998b) Characterization of $\gamma$ glutamylcysteine heavy subunit gene promoter: critical role for AP1. FEBS Lett 427: 129133

ROTRUCK JT, POPE AL, GANTHER HE, SWANSON AB, HAFEMAN DG, HOEKSTRA WG (1973) Selenium: biochemical role as a component of glutathione peroxidase. Science 179: 588590
SCHULZE OSTHOFF K, LOS M, BAEUERLE PA (1995) Redox signalling by transcription factors NF $\kappa \mathrm{B}$ and AP1 in lymphocytes. Biochem Pharmacol 50: 735741

SHALINI S, BANSAL MP (2005) Role of selenium in regulation of spermatogenesis: Involvement of activator protein 1. Biofactors 23: 151162

SHALINI S, BANSAL MP (2006) Alterations in selenium status influences reproductive potential of male mice by modulation of transcription factor NF $\kappa \mathrm{B}$. Biometals (in press)

SHARMA RK, AGARWAL A (1996) Role of reactive oxygen species in male infertility. Urology 48(6): 835 850

SHEN H, YANG C, DING W, LIU J, ONG C (2001) Superoxide radical initiated apoptotic signaling pathway in selenite treated HepG2 cell: Mitochondria serve as the main target. Free Radic Biol Med 30: 921

SHEN H, YANG C, LIU J, ONG C (2000) Dual role of glutathione in selenite induced oxidative stress and apoptosis in human hepatoma cells. Free Radic Biol Med 28(7): 11151124

SPYROU G, BJORNSTEDT M, KUMAR S, HOLMGREN A (1995) AP 1 DNA binding activity is inhibited by selenite and selenodiglutathione. FEBS Lett 368(1): 59 63

STADTMAN TC (1996) Selenocysteine. Annu Rev Biochem 65: 83100

STEINBERGER A (1975) Studies of spermatogenesis in vitro. Methods in Enzymol 39: 283296

TANAKA T, UCHIUMI T, KOHNO K, TOMONARI A, NISHIO K, SAIJO N, KONDO T, KUWANO M (1998) Glutathione homeostasis in human hepatic cells: overexpression of gamma glutamylcysteine synthetase gene in cell lines resistant to buthionine sulfoximine, an inhibitor of glutathione synthesis. Biochem Biophys Res Commun 246(2): 398403

TIAN D, SU M, XU X, WU X, LI Q, ZHENG R (2002) Effects of selenium and iodine on $\mathrm{c}$ fos and $\mathrm{c}$ jun mRNA and their protein expressions in cultured rat hippocampus cells. Biol Trace Elem Res 90(1 3): 175 186

TIAN L, SHI MM, ORMAN H J (1997) Increased transcription of the regulatory subunit of gamma glutamylcysteine synthetase in rat lung epithelial L2 cells exposed to oxidative stress or glutathione depletion. Arch Biochem Biophys 342(1): 126133

TORMOS C, JAVIER CHAVES F, GARCIA MJ, GARRIDO F, JOVER R, O'CONNOR JE, IRADI A, OLTRA A, OLIVA MR, SAEZ GT (2004) Role of glutathione in the induction of apoptosis and $\mathrm{c}$ fos and c jun mRNAs by oxidative stress in tumor cells. Cancer Lett 208(1): 103113

YAMADA K, TAKANE GYOTOKU, N, YUAN X, ICHIKAWA F, INADA C, NONAKA K (1996) Mouse islet cell lysis mediated by interleukin 1 induced Fas. Diabetologia 39: 13061312

YAN N, MEISTER A (1990) Amino acid sequence of rat kidney gamma glutamyl cysteine synthetase. J Biol Chem 265: 15881593 
